\title{
The adaptation of Rhizobium leguminosarum bv. phaseoli to oxidative stress and its overlap with other environmental stress responses
}

\author{
Ansley J. Crockford, Cecile Behncke and Huw D. Williams \\ Author for correspondence: Huw D. Williams. Tel: 0171594 5383. Fax: 01715842056. \\ e-mail: h.d.williams@ic.ac.uk
}

Department of Biology, Imperial College of

Science, Technology and Medicine, Prince Consort Road, London SW7 2BB, UK

\begin{abstract}
This paper reports the adaptation of Rhizobium leguminosarum bv. phaseoli to oxidative stress and the investigation of its overlap with other environmental stress responses. Treatment of $R$. leguminosarum bv. phaseoli cells with low concentrations of either menadione (MD, a superoxide generating agent) or 1-chloro-2,4-dinitrobenzene (CDNB, which depletes GSH levels) induced an adaptive response which resulted in cells becoming resistant to subsequent treatment with high concentrations of these oxidative stress compounds. There was overlap between the adaptive response to MD-generated superoxide stress and the response previously demonstrated in this organism to $\mathrm{H}_{2} \mathrm{O}_{2}$ (A. J. Crockford, G. A. Davis \& H. D. Williams, 1995, Microbiology 141, 843-851); pretreatment with $\mathrm{H}_{2} \mathrm{O}_{2}$ was protective against cell killing by MD and vice versa. In contrast, similar experiments indicated only a limited overlap between the responses to $\mathrm{H}_{2} \mathrm{O}_{2}$ and CDNB-mediated $\mathrm{GSH}$ depletion. It was also found that $\mathrm{H}_{2} \mathrm{O}_{2}$, but not MD or CDNB, adaptation protected cells against subsequent osmotic challenge and heat shock. Carbon-starved cells were more resistant to $\mathrm{H}_{2} \mathrm{O}_{2}$ and MD killing than exponentially growing cultures, but were more sensitive to CDNB-mediated GSH depletion. Therefore, this work shows that there is a substantial, but incomplete overlap between the responses of $R$. leguminosarum to different forms of oxidative and other environmental stresses.
\end{abstract}

Keywords: oxidative stress, starvation, osmotic stress, heat-shock, superoxide, glutathione, hydrogen peroxide

\section{INTRODUCTION}

Aerobic micro-organisms have to deal with reactive oxygen species such as the superoxide anion radical, $\mathrm{H}_{2} \mathrm{O}_{2}$ and the hydroxyl radical which are formed as an unavoidable consequence of an aerobic lifestyle (Fridovich, 1978; Halliwell \& Gutteridge, 1989). These oxidants can cause wide ranging damage to the living cell through their detrimental effects on key macromolecules (Brot et al., 1981; Demple \& Linn, 1982; Levin et al., 1982). Consequently, living organisms have evolved ways of protecting themselves against reactive oxygen species by the involvement of enzymic defence mechanisms such as catalase and superoxide dismutase, and through the synthesis of antioxidant molecules such as GSH (Halliwell \& Gutteridge, 1989).

Abbreviations: CDNB, 1-chloro-2,4-dinitrobenzene; MD, menadione.
The adaptation of bacteria to oxidative stress is best studied in enteric bacteria, where OxyR positively regulates the genes encoding the proteins involved in the adaptive response to $\mathrm{H}_{2} \mathrm{O}_{2}$, and the SoxR and SoxS proteins are essential regulators of the superoxide adaptive response (Christman et al., 1989; Demple, 1991). There is a degree of overlap between the two oxidative stress responses and they overlap with the SOS and heat-shock adaptations (Demple, 1991; Farr \& Kogoma, 1991). $\mathrm{H}_{2} \mathrm{O}_{2}$-adapted enteric bacteria show increased resistance to heat and 2-D PAGE shows that there are some common proteins synthesized during oxidative stress and nutrient starvation (Nystrom, 1993; Christman et al., 1985; Siegle \& Kolter, 1992).

We are currently investigating the response of the symbiotic nitrogen-fixing bacterium Rbizobium leguminosarum bv. phaseoli to environmental stress in an attempt to understand its ability to adapt to and survive in adverse 
soil conditions and how stress might affect its ability to form nitrogen-fixing symbioses with leguminous plants (Graham, 1992). Little is known about the physiological responses of Rbizobium spp. to the kinds of stress they might encounter in the soil, during nodulation or when differentiated into bacteroids in the mature, nitrogenfixing root nodule. However, a number of stress conditions are known to interfere with the development and function of the Rhizobium-legume symbiosis, including temperature, acid and osmotic stresses (La Favre et al., 1986; Michiels et al., 1994; Zahran \& Sprent 1986; Evans et al., 1980). Adaptation to acid stress is probably the best studied stress response in Rbizobium spp. and a positive correlation has been found between acid tolerance, exopolysaccharide production and the ability to generate a $\mathrm{pH}$ gradient under acid conditions (Tiwari et al., 1992; O'Hara et al., 1989; Chen et al., 1993). In R. leguminosarum bv. trifolii there is evidence that acid tolerance is linked to a megaplasmid which also carries certain symbiotic nitrogen-fixing functions (Chen et al., 1993).

We have previously reported that $\mathrm{R}$. leguminosarum can mount an adaptive response to $\mathrm{H}_{2} \mathrm{O}_{2}$-mediated oxidative stress and this response involved a modest induction of catalase activities (Crockford et al., 1995). Interestingly, catalase showed cell-density-dependent regulation controlled by the accumulation of extracellular components in the growth medium. This paper extends our previous work to study the response of these bacteria to other forms of oxidative stress and investigates the extent of cross-protection between adaptation to different oxidative stress agents. We also investigate whether oxidatively stressed $R$. leguminosarum cells acquire resistance to other environmental stress conditions such as osmotic, heatshock and starvation stresses.

\section{METHODS}

Bacteria and growth conditions. Rhizobium leguminosarum bv. phaseoli strain 4292 used in this study was kindly provided by $\mathrm{Dr}$ Allan Downie. It is a rifampicin-resistant strain which carries the bv. phaseoli Sym plasmid pRP2JI (Lamb et al., 1982). It was grown in YEM medium at $\mathrm{pH} 7 \cdot 5$ (Vincent, 1970) comprising $\left(\mathrm{g} \mathrm{l}^{-1}\right)$ : yeast extract $\left(0 \cdot 4\right.$, Oxoid), $\mathrm{K}_{2} \mathrm{HPO}_{4}(0 \cdot 5), \mathrm{NaCl}(0 \cdot 1)$, $\mathrm{MgSO}_{4} \cdot 7 \mathrm{H}_{2} \mathrm{O}(0 \cdot 2)$, mannitol (10), or TY medium comprising $\left(\mathrm{g} \mathrm{l}^{-1}\right)$ : bactotryptone (5), yeast extract (3), $\mathrm{CaCl}_{2} \cdot 6 \mathrm{H}_{2} \mathrm{O}(1 \cdot 3)$. For solid medium, agar was added at $15 \mathrm{~g} \mathrm{l}^{-1}$. For routine culture maintenance, growth of starter cultures and for plating for viable counting, rifampicin was added at $25 \mu \mathrm{g} \mathrm{ml}^{-1}$, but it was not added to cultures used in stress experiments.

Culture methods for stress treatments and adaptation experiments. Strain 4292 was inoculated into YEM medium and grown with shaking (200 r.p.m.) at $30^{\circ} \mathrm{C}$ to an $\mathrm{OD}_{600}$ of $0 \cdot 2$, the $\mathrm{pH}$ of the culture at this stage being about $7 \cdot 45$. Aliquots $(5 \mathrm{ml})$ of the culture were transferred into sterile tubes and $\mathrm{H}_{2} \mathrm{O}_{2}$, menadione (MD), 1-chloro-2,4-dinitrobenzene (CDNB) or $\mathrm{NaCl}$ added to the desired final concentration. The cultures were then incubated as before. For heat-shock experiments, cultures were shifted from $30^{\circ} \mathrm{C}$ to $45^{\circ} \mathrm{C}$. Samples were taken immediately prior to and periodically after the stress addition, diluted in YEM minus mannitol and plated onto TY agar containing rifampicin $\left(25 \mu \mathrm{g} \mathrm{ml}^{-1}\right)$ to monitor cell viability. Colonies were counted after $3-4 \mathrm{~d}$ incubation at $30^{\circ} \mathrm{C}$. For adaptation experiments, overnight cultures were used to inoculate $50 \mathrm{ml}$ YEM to an initial $\mathrm{OD}_{600}$ of $0 \cdot 01$. When the culture had grown to reach an $\mathrm{OD}_{600}$ of $0 \cdot 2, \mathrm{H}_{2} \mathrm{O}_{2}, \mathrm{MD}$ or CDNB was added to a final concentration of $200 \mu \mathrm{M}$. After the pretreated cells had been incubated for $2 \mathrm{~h}$, a sample was taken to determine culture viability and then $\mathrm{H}_{2} \mathrm{O}_{2}, \mathrm{MD}$ or CDNB was added to a final concentration of 3,50 or $2 \mathrm{mM}$, respectively, or for osmotic stress $\mathrm{NaCl}$ was added to $2.5 \mathrm{M}$ and the culture sampled at intervals for viable counting. Heat-shock was achieved by shifting the culture to $45^{\circ} \mathrm{C}$. R. Leguminosarum 4292 cultures were carbon-starved by growing in YEM containing $0.01 \%$ mannitol to stationary phase $\left(\mathrm{OD}_{600} 0.5\right)$.

\section{RESULTS AND DISCUSSION}

\section{Adaptation of $R$. leguminosarum bv. phaseoli to MD and CDNB}

R. leguminosarum can adapt to $\mathrm{H}_{2} \mathrm{O}_{2}$-induced oxidative stress (Crockford $e t$ al., 1995) and we were interested to determine if it could also adapt to other forms of oxidative stress, in particular the superoxide anion radical and depletion of the antioxidant molecule GSH. MD is a quinone that generates superoxide in vivo by redox cycling reactions (Halliwell \& Gutteridge, 1989). To determine the degree of sensitivity of $R$. leguminosarum to $M D$, exponentially growing cultures were harvested and exposed to MD concentrations from 0.1 to $50 \mathrm{mM}$ and their viability followed. Concentrations of $\mathrm{MD}$ as high as $10 \mathrm{mM}$ had little or no effect on viability, but at $50 \mathrm{mM}$ MD viability was quickly lost (data not shown). To look at the ability of $R$. leguminosarum to adapt to $M D$, exponentially growing cultures were pretreated with a sub-lethal dose of $\mathrm{MD}(200 \mu \mathrm{M})$ for $2 \mathrm{~h}$ and subsequently challenged with a $50 \mathrm{mM}$ dose of MD and cell viability followed. The results in Fig. 1(a) show that pretreating cultures with $200 \mu \mathrm{M}$ MD led to considerably increased survival compared to untreated cultures. For example, $6 \mathrm{~h}$ after addition of the lethal MD concentration, $73 \%$ survival was found in pretreated cultures compared to just $21 \%$ survival in the untreated cultures. Cultures pretreated with MD in the presence of chloramphenicol $\left(100 \mu \mathrm{g} \mathrm{ml}^{-1}\right)$ did not acquire any resistance to $50 \mathrm{mM}$ MD (Fig. 1a), indicating that de novo protein synthesis is required for adaptation of $R$. leguminosarum to $M D$ generated superoxide stress. Therefore, in its ability to adapt to $\mathrm{H}_{2} \mathrm{O}_{2}$ (Crockford et al., 1995) and superoxide stress, $R$. leguminosarum shows a similar response to Escherichia coli (Demple \& Halbrook, 1983), Salmonella typhimurium (Christman et al., 1985), Bacillus subtilis (Dowds et al., 1987) and yeast (Flattery-O'Brian et al., 1993; Collinson \& Dawes, 1992; Jamieson, 1992).

CDNB causes oxidative stress by depleting the intracellular levels of the antioxidant molecule GSH by forming conjugates with GSH, either spontaneously or by enzyme-catalysed reactions with GSH-transferases (Plummer et al., 1981; Habig \& Jakoby, 1981; Christman et al., 1985). GSH is a ubiquitous tripeptide that has a protective effect in both mammalian and bacterial cells against oxidative damage by removing hydroperoxides. It is present at high levels $(5-10 \mathrm{mM})$ in some bacteria, such as E. coli (Apontoweil \& Berenda, 1975) and the presence 


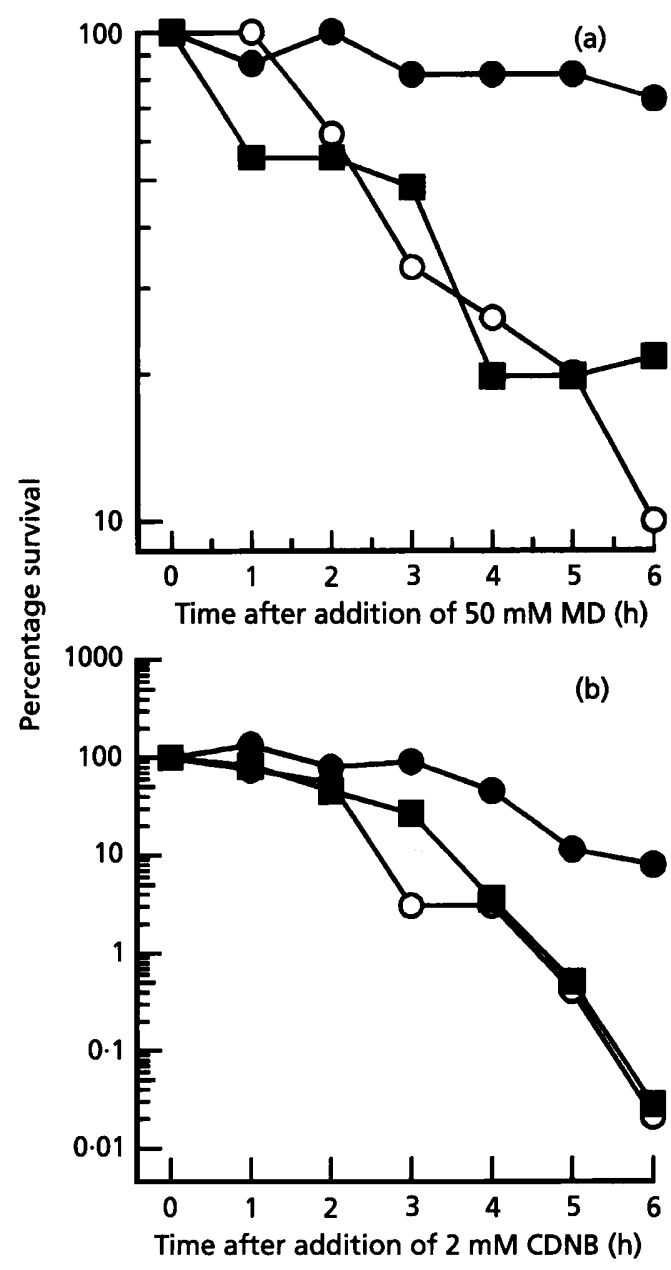

Fig. 1. Adaptation of $R$. leguminosarum to MD and CDNB. Cells were grown exponentially in YEM medium to an $O_{600}$ of 0.2 $\left(4 \times 10^{8}\right.$ c.f.u. $\left.\mathrm{ml}^{-1}\right)$, which represents $100 \%$ survival, and then pretreated with $200 \mu \mathrm{M}$ MD (a) or $200 \mu \mathrm{M}$ CDNB (b) for $2 \mathrm{~h}$ in the presence and absence of chloramphenicol $\left(100 \mu \mathrm{g} \mathrm{ml}^{-1}\right)$. After $2 \mathrm{~h}, \mathrm{MD}$ (a) or CDNB (b) were added to cultures at final concentrations of $50 \mathrm{mM}$ and $2 \mathrm{mM}$, respectively, and samples were taken to determine cell viability. Symbols: no pretreatment $(\square)$, pretreated in the presence $(O)$ and absence (O) of chloramphenicol. Data points are mean values of duplicates from a representative experiment.

of GSH-reductase in the plant fraction of extracts from nitrogen-fixing root nodules is evidence that GSH may play a role in the root nodule tissue as a defence against $\mathrm{H}_{2} \mathrm{O}_{2}$ (Dalton et al., 1986). The effect of concentrations of CDNB from $0 \cdot 1-5 \mathrm{mM}$ on the viability of growing $R$. leguminosarum cultures was investigated. CDNB had no effect at $0.1 \mathrm{mM}$, but following addition of $2 \mathrm{mM} \mathrm{CDNB}$, viability was rapidly lost. The data in Fig. 1(b) show that cultures pretreated with a non-lethal dose of $C D N B$ were considerably more resistant to killing following addition of a lethal concentration, demonstrating that $R$. leguminosarum can mount an adaptive response to CDNB-mediated GSH depletion. For example, $6 \mathrm{~h}$ after addition of $2 \mathrm{mM}$ CDNB there was $7 \cdot 7 \%$ and $0.023 \%$ survival in the pretreated and untreated cultures, respectively. Cultures pretreated in the presence of chloramphenicol did not acquire CDNB resistance, indicating that de novo protein synthesis is required for adaptation of $R$. leguminosarum to GSH depletion by CDNB (Fig. 1b). The observation that $R$. leguminosarum can adapt to CDNB implies a role for $\mathrm{GSH}$ in oxidative stress protection in this bacterium.

\section{Overlap between $R$. leguminosarum adaptive responses to oxidative stress agents}

E. coli possesses a regulatory response to superoxide anions that is distinct from that involved in protecting cells against $\mathrm{H}_{2} \mathrm{O}_{2}$ (Farr \& Kogoma, 1991), while in $S$. typhimurium pre-adaptation to $\mathrm{H}_{2} \mathrm{O}_{2}$ leads to greater resistance to MD (Christman et al., 1985). The proteins induced by these individual stresses comprise largely separate regulons controlled by OxyR and the SoxR-SoxS proteins, respectively (Demple, 1991). Therefore, we investigated whether the $R$. leguminosarum adaptive response to $\mathrm{H}_{2} \mathrm{O}_{2}$ (Crockford et al., 1995) was distinct from those demonstrated above to MD and CDNB. R. leguminosarum cultures were exposed to doses of $\mathrm{H}_{2} \mathrm{O}_{2}$, $\mathrm{MD}$ or $\mathrm{CDNB}$, capable of inducing adaptive responses (Fig. 1; Crockford et al., 1995), and after a $2 \mathrm{~h}$ adaptation period, cultures were challenged with lethal doses of the various oxidative stress agents. The results of these experiments (Fig. 2) indicated that cross-protection against $\mathrm{H}_{2} \mathrm{O}_{2}$ killing was obtained by pretreating cells with MD or CDNB (Fig. 2a). Similarly, pretreatment of cultures with a low concentration of $\mathrm{H}_{2} \mathrm{O}_{2}$ gave modest, but reproducible, cross-protection against MD (Fig. 2b). In contrast, pretreatment with a low concentration of CDNB resulted in a small sensitizing effect to subsequent MD treatment as shown by the reduced survival of pretreated compared to untreated cultures (Fig. 2b). Similarly, adaptation of cultures to $\mathrm{H}_{2} \mathrm{O}_{2}$ or MD led to a reduction in survival, very marked with $\mathrm{MD}$, following CDNB treatment (Fig. 2c). This may be due to the $\mathrm{H}_{2} \mathrm{O}_{2}$ and particularly the MD treatment depleting intracellular GSH reserves prior to CDNB treatment. The data imply that there is significant overlap between the adaptive responses of $R$. leguminosarum to $\mathrm{H}_{2} \mathrm{O}_{2}$ and superoxidemediated stress. In contrast, there is only limited overlap between the responses to $\mathrm{H}_{2} \mathrm{O}_{2}$ and $\mathrm{CDNB}$, as pretreatment with CDNB afforded cross-protection against $\mathrm{H}_{2} \mathrm{O}_{2}$ but not vice versa, and no overlap in the responses to $\mathrm{MD}$ and $\mathrm{CDNB}$. Therefore, the adaptive response to GSH depletion, mediated by CDNB, is distinct from those to $\mathrm{H}_{2} \mathrm{O}_{2}$ and superoxide.

The apparent sensitization effect on cells of MD treatment to CDNB killing may reflect the presence of acutely superoxide-sensitive proteins. In $E$. coli the enzymes 6-phosphogluconate dehydrogenase, $\alpha, \beta$-dihydroxyisovalerate dehydratase and aconitase are particularly sensitive to superoxide (Gardner \& Fridovich, 1991a, b; Kuo et al., 1987), but can be reactivated by GSH. A plausible explanation of our data is that nonlethal doses of MD may inactivate superoxide-sensitive enzymes in R. leguminosarum. Consequently, GSH levels become depleted during reactivation processes making 

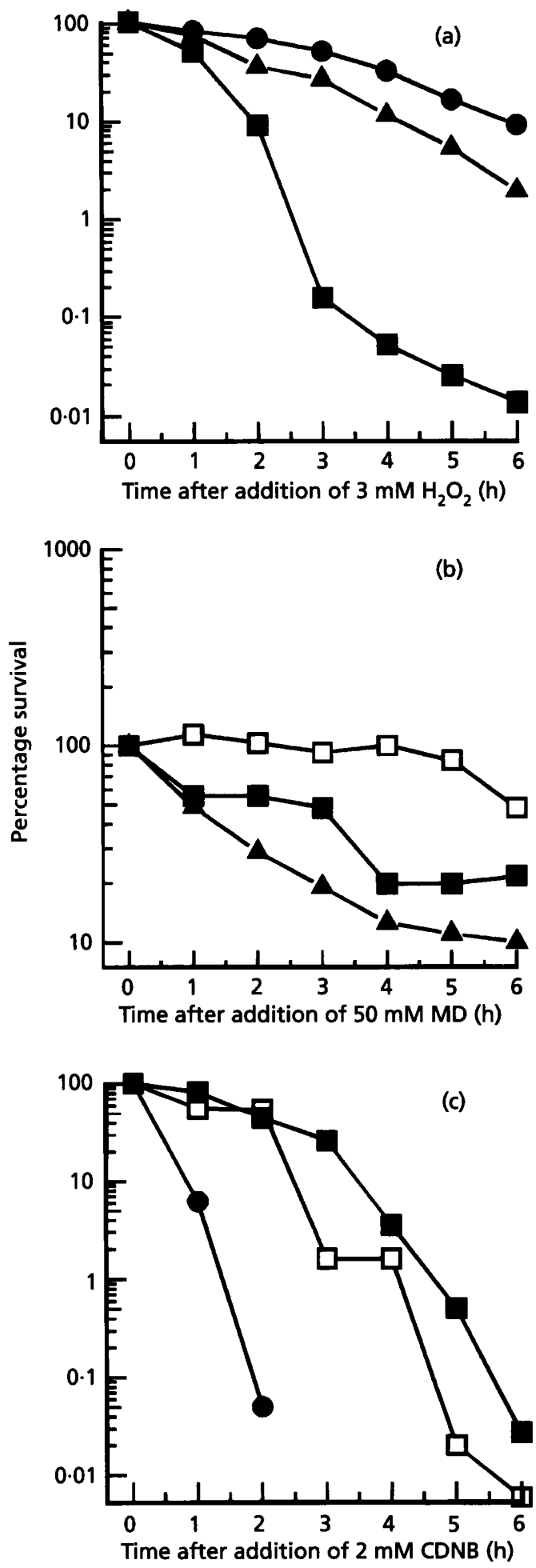

Fig. 2. Overlap between $R$. leguminosarum adaptive responses to oxidative stress agents. $R$. leguminosarum cultures were grown as described in the legend to Fig. 1 and then pretreated with $\mathrm{H}_{2} \mathrm{O}_{2}(\square)$, MD (O) or CDNB $(\boldsymbol{\Lambda})$ at concentrations of $200 \mu \mathrm{M}$ or left untreated ( $\square$ ). After $2 \mathrm{~h}, \mathrm{H}_{2} \mathrm{O}_{2}$ (a), MD (b) or CDNB (c) were added to all cultures to final concentrations of 3 , 50 and $2 \mathrm{mM}$, respectively, and samples were taken periodically to determine cell viability. Data points are mean values of duplicates from a representative experiment. the cells acutely sensitive to subsequent $\mathrm{CDNB}$ treatment. A similar explanation could account for the sensitizing effect of $\mathrm{H}_{2} \mathrm{O}_{2}$ pretreatment prior to $\mathrm{CDNB}$ challenge. An additional factor might be the depletion of intracellular $\mathrm{NAD}(\mathrm{P}) \mathrm{H}$ levels via redox cycling reactions of $\mathrm{MD}$ compromising the ability of the NADPH-requiring enzyme GSH-reductase to regenerate GSH from GSSG, prior to CDNB addition.

\section{Investigation of the overlap between oxidative stress and other stresses}

Considerable overlap between different stress responses, including oxidative stress has been demonstrated in enteric bacteria (Farr \& Kogoma, 1991). In their soil environment rhizobia would frequently encounter a range of environmental stress conditions (Graham, 1992). Therefore, we looked at the survival responses of $R$. leguminosarum to various environmental stresses including osmotic stress, heat-shock and carbon starvation and their overlap with the oxidative stress responses. Preliminary experiments showed that exponentially growing cultures were killed fairly rapidly when osmotically stressed by addition of $\mathrm{NaCl}$ to a final concentration of $2.5 \mathrm{M}$. To determine if there was cross-protection between oxidative stress and osmotic stress, exponentially growing cultures were exposed to non-lethal doses of $\mathrm{H}_{2} \mathrm{O}_{2}, \mathrm{MD}$ or CDNB (all at $200 \mu \mathrm{M}$ ) for $2 \mathrm{~h}$ prior to challenge with $2.5 \mathrm{M} \mathrm{NaCl}$. The data in Fig. 3(a) show that prior $\mathrm{H}_{2} \mathrm{O}_{2}$ adaptation was very effective in protecting against osmotic challenge. After $5 \mathrm{~h}, \mathrm{H}_{2} \mathrm{O}_{2}$-adapted cultures showed $1.5 \%$ survival compared to $0.14 \%$ in the non-adapted culture. Osmotic stress survival was not enhanced by pretreatment with MD or CDNB (Fig. 3a). Similarly, to determine whether there was cross-protection between oxidative stress and thermotolerance, cultures preadapted to $\mathrm{H}_{2} \mathrm{O}_{2}, \mathrm{MD}$ or $\mathrm{CDNB}$ at $30^{\circ} \mathrm{C}$ were shifted to $45^{\circ} \mathrm{C}$ and their viability followed. $\mathrm{H}_{2} \mathrm{O}_{2}$-adapted cultures showed modestly increased survival compared to the non-adapted culture, while both MD and CDNB adaptation led to a small decline in survival relative to the control (Fig. 3b).

In response to osmotic stress, R. meliloti synthesizes trehalose as a compatible solute (Breedveld et al., 1990, 1993) and also accumulates the disaccharide under microoxic conditions (Hoelzle \& Streeter, 1990). It has recently been proposed that trehalose might function as a general stress protectant in microbes rather than simply a reserve of carbon and energy (Strom \& Kaasen, 1993). So a possible explanation for cross-protection against different stress conditions may be the induction of a general stress protectant such as trehalose. Some proteins, identified originally as heat-shock proteins, may act as general antistress proteins; for example, the heat-shock proteins GroES and GroEL are induced by peroxide and superoxide-mediated oxidative stress as well as by starvation and DNA damage in enteric bacteria (Farr \& Kogoma, 1991).

Stationary phase cultures of $\mathrm{R}$. leguminosarum are more resistant to $\mathrm{H}_{2} \mathrm{O}_{2}$ than exponential cultures and resistance is not linked to increased catalase activity (Crockford $e t$ 


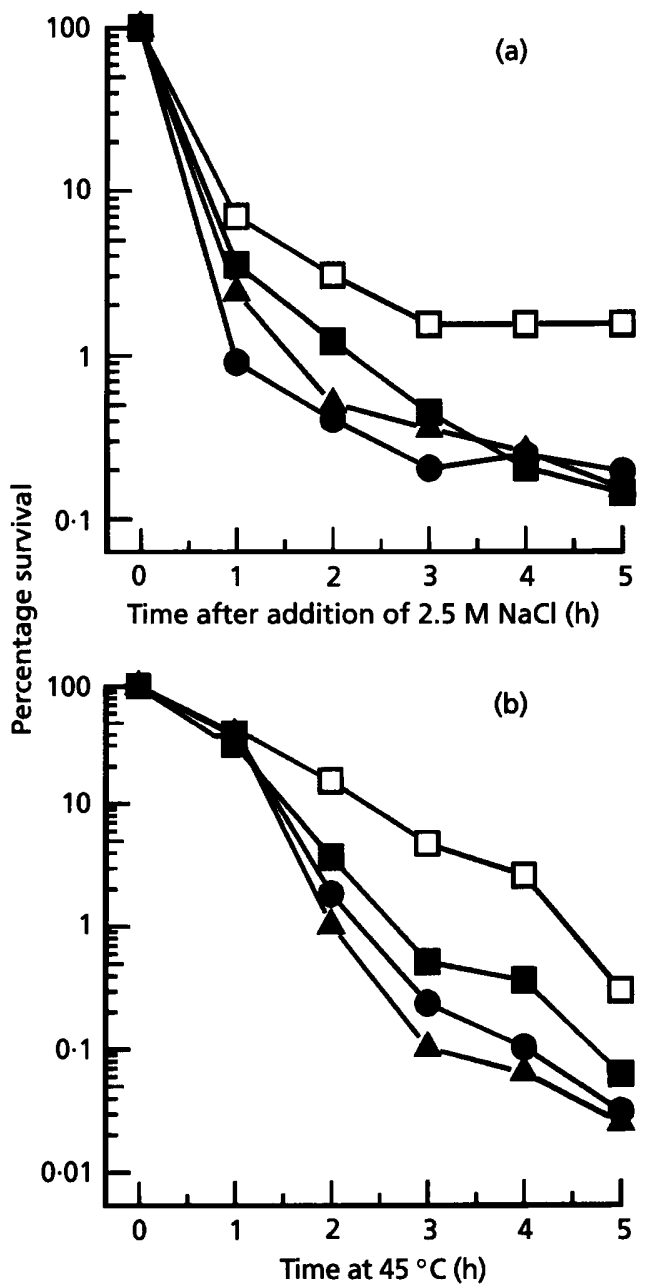

Fig. 3. Overlap between adaptive responses of $R$. leguminosarum to oxidative stress agents and osmotic stress and heat-shock. $R$. leguminosarum cultures were grown as described in the legend to Fig. 1 and then pretreated with $\mathrm{H}_{2} \mathrm{O}_{2}$ ( $\square$ ), MD (O) or CDNB (A) at concentrations of $200 \mu \mathrm{M}$ or left untreated ( $\square$ ). After $2 \mathrm{~h}$, cultures were either subjected to osmotic stress by addition of $\mathrm{NaCl}$ to a final concentration of $2.5 \mathrm{M}$ (a) or heat-shocked by shifting the temperature from $30^{\circ} \mathrm{C}$ to $45^{\circ} \mathrm{C}$ (b). Samples were taken periodically to determine cell viability. Data points are mean values of duplicates from a representative experiment.

al., 1995). Stationary phase cultures of a number of different bacteria are very resistant to a variety of stresses, including oxidative stress, as indeed are cultures starved of specific nutrients (Siegle \& Kolter, 1992; Nystrom, 1993). To establish whether $R$. leguminosarum has a similar response, the effects of oxidative stress on carbon-starved $R$. leguminosarum were compared with those of exponentially growing cultures. Growth of $R$. leguminosarum in YEM containing $0.01 \%(\mathrm{w} / \mathrm{v})$ mannitol, in contrast to the usual concentration of $1 \%$, led to the culture entering stationary phase at an $\mathrm{OD}_{600}$ of 0.53 rather than 1.5 . We concluded that the premature entry into stationary phase resulted from carbon-limitation of growth. The YEM medium has a low buffering capacity which would be

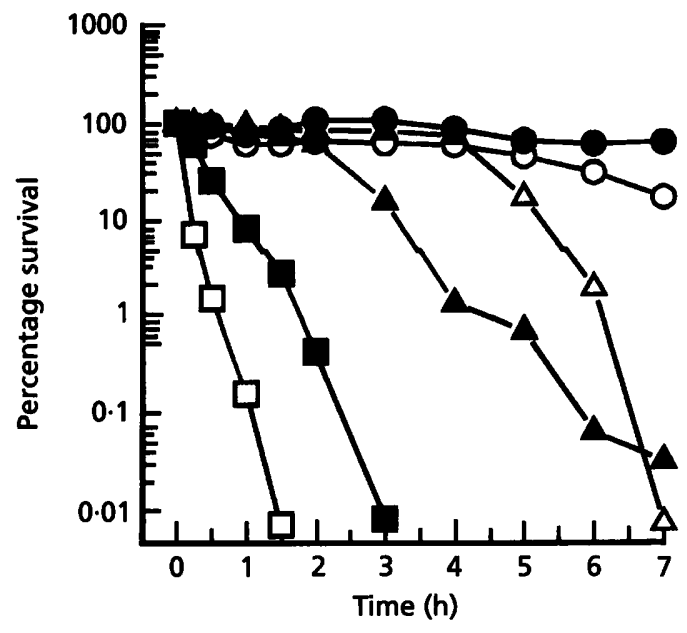

Fig. 4. The effect of carbon starvation on the ability of $R$. leguminosarum to survive oxidative stress. Exponentially growing cultures (open symbols) or cultures which had been in a carbon-starvation-induced stationary phase for $4 \mathrm{~h}$ (closed symbols) were treated with (final concentration) $\mathrm{H}_{2} \mathrm{O}_{2}(5 \mathrm{mM}$, $\square, \square)$ MD ( $50 \mathrm{mM}, O, 0)$ or CDNB $(2 \mathrm{mM}, \Delta, \Delta)$ and samples were taken periodically to determine cell viability. Data points are mean values of duplicates from a representative experiment.

further reduced in the carbon starvation medium. However, it seems unlikely that the responses of exponentially growing and starved cultures to oxidative stress were unduly complicated by differences in the $\mathrm{pH}$ of the two cultures as the growing culture was at $\mathrm{pH} 7 \cdot 45\left(\mathrm{OD}_{600} 0 \cdot 2\right)$ and the carbon-starved, stationary phase culture was at $\mathrm{pH}$ 7·7. Fig. 4 shows that carbon-starved R. leguminosarum are significantly more resistant to $\mathrm{H}_{2} \mathrm{O}_{2}$ than growing cultures. After a $5 \mathrm{mM} \mathrm{H}_{2} \mathrm{O}_{2}$ challenge of $1.5 \mathrm{~h}$, there was $2.5 \%$ viability in the starved culture but only $0.007 \%$ in the growing culture. Carbon-starved cells were also more resistant to $\mathrm{MD}$, with $60 \%$ viability in starved cultures after $7 \mathrm{~h}$, compared to just $16 \%$ in the growing cultures. In contrast, exponentially growing cells were significantly more resistant to CDNB than starved cells. A possible explanation for this is that starved cells carefully control the regeneration of GSH from GSSG as it could only be achieved in carbon-starved cultures at the expense of reducing power derived from vital endogenous reserves. Consequently, starved cells may be sensitized to CDNBmediated GSH depletion. These data indicate overlap in the adaptation of $R$. leguminosarum to carbon starvation and oxidative stress, but also show again a difference in the response to GSH depletion.

\section{REFERENCES}

Apontoweil, P. \& Berenda, W. (1975). Glutathione biosynthesis in Escherichia coli $\mathrm{K} 12$. Properties of the enzyme and regulation. Biochim Biophys Acta 399, 1-9.

Breedveld, M. W., Zevenhuizen, L. P. J. M. \& Zehnder, A. J. B. (1990). Osmotically induced oligo- and polysaccharide synthesis by Rbizobium melitoli SU-47. J Gen Microbiol 136, 2511-2519. 
Breedveld, M. W., Ludovicus, C. D., Zevenhuizen, L. P. T. M. \& Zehnder, A. J. B. (1993). Response of intracellular carbohydrates to a $\mathrm{NaCl}$ shock in Rhizobium leguminosarum biovar trifolii TA-1 and Rbizobium meliloli SU-47. J Gen Microbiol 139, 3157-3163.

Brot, N., Weissbach, L., Werth, J. \& Weisbach, H. (1981). Enzymatic reduction of protein-bound methionine sulfoxide. Proc Natl Acad Sci US A 78, 2155-2158.

Chen, H., Gartner, E. \& Rolfe, B. G. (1993). Involvement of genes on a megaplasmid in the acid tolerant phenotype of Rbizobium leguminosarum biovar trifolii. Appl Environ Microbiol 59, 1058-1064.

Christman, M. F., Morgan, R. W., Jacobson, F. S. \& Ames, B. N. (1985). Positive control of a regulon for defenses against oxidative stress and some heat-shock proteins in Salmonella typhimurium. Cell 41, 753-762.

Christman, M. F., Storz, G. \& Ames, B. N. (1989). OxyR, a positive regulator of hydrogen peroxide-inducible genes in Eschericbia coli and Salmonella typhimurium, is homologous to a family of bacterial regulatory proteins. Proc Natl Acad Sci USA 86, 3484-3488.

Collinson, L. P. \& Dawes, I. W. (1992). Inducibility of the response of yeast cells to peroxide stress. J Gen Microbiol 138, 329-335.

Crockford, A. J., Davis, G. A. \& Williams, H. D. (1995). Evidence for cell-density-dependent regulation of catalase activity in Rhizobium leguminosarum bv. phaseoli. Microbiology 141, 843-851.

Dalton, D. A., Russell, S. A., Hanus, F. J., Pascoe, G. A. \& Evans, H. J. (1986). Enzymatic reactions of ascorbate and glutathione that prevent peroxide damage in soybean root nodules. Proc Natl Acad Sci US A 83, 3811-3815.

Demple, B. (1991). Regulation of bacterial oxidative stress genes. Annu Rev Genet 25, 315-337.

Demple, B. \& Halbrook, J. (1983). Inducible repair of oxidative DNA damage in Escherichia coli. Nature 304, 466-468.

Demple, B. \& Linn, S. (1982). 5,6-Saturated thymine lesions in DNA production by ultraviolet light and hydrogen peroxide. Nucleic Acids Res 10, 3781-3789.

Dowds, B. C., Murphy, P., McConnell, D. J. \& Devine, K. M. (1987). Relationship among oxidative stress, growth cycle and sporulation in Bacillus subtilis. J Bacteriol 169, 5771-5775.

Evans, L. S., Lewin, K. F. \& Vella, F. A. (1980). Effect of nutrient medium $\mathrm{pH}$ on symbiotic nitrogen fixation by Rhizobium leguminosarum and Pisum sativum. Plant Soil 56, 71-80.

Farr, S. \& Kogoma, T. (1991). Oxidative stress responses in Escherichia coli and Salmonella typhimurium. Microbiol Rev 55, 561-585.

Flattery-O'Brian, J., Collinson, L. P. \& Dawes, I. W. (1993). Saccharomyces cerevisiae has an inducible response to menadione which differs from that to hydrogen peroxide. J Gen Microbiol 139, 501-507.

Fridovich, I. (1978). The biology of oxygen radicals. Science 201, 875-880.

Gardner, P. R. \& Fridovich, I. (1991a). Superoxide sensitivity of the Escherichia coli 6-phosphogluconate dehydratase. J Biol Chem 266, 1478-1483.

Gardner, P. R. \& Fridovich, I. (1991b). Superoxide sensitivity of the Eschericbia coli aconitase. J Biol Chem 266, 19328-19333.
Graham, P. H. (1992). Stress tolerance in Rbizobium and Bradyrbizobium, and nodulation under adverse soil conditions. Can $J$ Microbiol 38, 475-484.

Habig, W. H. \& Jakoby, W. B. (1981). Glutathione-S-transferases (rat and human). Methods Enzymol 77, 50-59.

Halliwell, B. \& Gutteridge, J. M. C. (1989). Free Radicals in Biology and Medicine. Oxford: Clarendon Press.

Hoelzle, I. \& Streeter, J. G. (1990). Increased accumulation of trehalose in rhizobia cultured under 1 percent oxygen. Appl Environ Microbiol 56, 3213-3215.

Jamieson, D. J. (1992). Saccharomyces cerevisiae has distinct adaptive responses to both hydrogen peroxide and menadione. $J$ Bacteriol 174, 6678-6681.

Kuo, C. F., Mashino, T. \& Fridovich, I. (1987). $\alpha, \beta-$ Dihydroxyisovalerate dehydratase. A superoxide-sensitive enzyme. $J$ Biol Chem 262, 4724-4727.

La Favre, A. K. \& Eaglesham, A. R. J. (1986). The effects of high temperatures on soybean nodulation and growth with different strains of bradyrhizobia. Can J Microbiol 32, 22-27.

Lamb, J. W., Hombrecher, G. \& Johnston, A. W. B. (1982). Plasmid determined nodulation and nitrogen-fixation ability in Rbizobium phaseoli. Mol \& Gen Genet 186, 449-452.

Levin, D. E., Hollstein, M., Christman, M. F., Schwiers, E. A. \& Ames, B. N. (1982). A new Salmonella tester strain (TA102) with AT base pairs at the site of mutation detects oxidative mutagens. Proc Natl Acad Sci USA 79, 7445-7449.

Michiels, J., Verreth, C. \& Vanderleyden, J. (1994). Effects of temperature stress on bean-nodulating Rbizobium strains. Appl Environ Microbiol 60, 1206-1212.

Nystrom, T. (1993). In Starvation in Bacteria, pp. 129-150. Edited by S. Kjelleberg. New York: Plenum.

O'Hara, G. W., Goss, T. J., Dilworth, M. J. \& Glenn, A. R. (1989). Maintenance of intracellular $\mathrm{pH}$ and acid tolerance in Rhizobium meliloti. Appl Environ Microbiol 55, 1870-1876.

Plummer, J. L., Smith, B. R., Sies, H. \& Bend, J. R. (1981). Chemical depletion of glutathione in vivo. Methods Enzymol 77, 50-59.

Siegle, D. A. \& Kolter, R. (1992). Life after log. J Bacteriol 174, 345-348.

Strom, A. R. \& Kaasen, I. (1993). Trehalose metabolism in Escherichia coli: stress protection and stress regulation of gene expression. Mol Microbiol 8, 205-210.

Tiwari, R. P., Reeve, W. G. \& Glenn, A. R. (1992). Mutations conferring acid sensitivity in the acid-tolerant strains Rbizobium meliloti WSM419 and Rhizobium leguminosarum biovar viciae WAM710. FEMS Microbiol Lett 100, 107-112.

Vincent, J. M. (1970). A Manual for the Practical Study of Rootnodule Bacteria. Oxford: Blackwell.

Zahran, H. H. \& Sprent, J. I. (1986). Effects of sodium chloride and polyethylene glycol on root-hair infection and nodulation of Vicia faba in plants by Rbizobium leguminosarum. Planta 167, 303-309.

Received 9 May 1995; revised 6 September 1995; accepted 28 September 1995. 